\title{
Corrigendum: Your Brain on Art: Emergent Cortical Dynamics During Aesthetic Experiences
}

\author{
Kimberly L. Kontson * \\ Office of Science and Engineering Laboratories, Division of Biomedical Physics, Center for Devices and Radiological Health, \\ U.S. Food and Drug Administration, Silver Spring, MD, USA
}

Keywords: EEG, machine learning, functional connectivity (FC), aesthetics, freely moving

\section{A corrigendum on}

\section{OPEN ACCESS}

Edited and reviewed by: Marcos Nadal,

University of Vienna, Austria

*Correspondence:

Kimberly L. Kontson kimberly.kontson@fda.hhs.gov

Received: 23 November 2015 Accepted: 03 December 2015 Published: 16 December 2015

Citation:

Kontson KL (2015) Corrigendum: Your Brain on Art: Emergent Cortical

Dynamics During Aesthetic Experiences.

Front. Hum. Neurosci. 9:684. doi: 10.3389/fnhum.2015.00684
Your Brain on Art: Emergent Cortical Dynamics During Aesthetic Experiences

by Kontson, K. L., Megjhani, M., Brantley, J. A., Cruz-Garza, J. G., Nakagome, S., Robleto, D., et al. (2015). Front. Hum. Neurosci. 9:626. doi: 10.3389/fnhum.2015.00626

In Table 1, the descriptions for Piece 6 and Piece 7 should read as follows:

Piece 6: The Pulse Armed With a Pen (An Unknown History of the Human Heartbeat), 2013-2014. Custom-cut five-inch vinyl records, audio recordings, archival digital prints (record sleeves and linear notes), prints of three centuries of various human pulse and heartbeat tracings.

Piece 7: Max Ernst, Undulating Earthquake (Tremblement de terre ondulatoire), 1928. Oil on canvas mounted on masonite. The Menil Collection, Houston.

Conflict of Interest Statement: The author declares that the research was conducted in the absence of any commercial or financial relationships that could be construed as a potential conflict of interest.

Copyright $\odot 2015$ Kontson. This is an open-access article distributed under the terms of the Creative Commons Attribution License (CC BY). The use, distribution or reproduction in other forums is permitted, provided the original author(s) or licensor are credited and that the original publication in this journal is cited, in accordance with accepted academic practice. No use, distribution or reproduction is permitted which does not comply with these terms. 